\title{
Diversification in the Field of Furniture Retail of Russia
}

Tatiana L. Bezrukova

\author{
Voronezh State Academy of Forestry and Technologies, Voronezh, Russia
} bezrukova_t_@@mail.ru

Yulia N. Stepanova

Voronezh State Academy of Forestry and Technologies (VSAFT), Voronezh, Russia julia_vrn@inbox.ru

Yulia V. Busarina

Voronezh State Academy of Forestry and Technologies (VSAFT), Voronezh, Russia busarina.julia@mail.ru

Elena A. Yakovleva

Voronezh State Academy of Forestry and Technologies (VSAFT), Voronezh, Russia elena-12-27@mail.ru

\section{Alicher Sh. Subkhonberdiev}

Voronezh State Academy of Forestry and Technologies (VSAFT), Voronezh, Russia alisher-man@mail.ru

\section{Doi:10.5901/mjss.2015.v6n3s6p39}

Abstract

This article "Diversification of furniture retail of $R F$ " is devoted to finding ways of development of Russian furniture retail. The article analyzes the major trends of the industry, the prospects for development of the Russian furniture retail and key retail formats. An important component of this - is possibility of active development of furniture retailing in the context of macroeconomic indicators of the Russian Federation. Large-scale furniture sites today mostly determine the development of the market and the main aspects of its functioning. In the global furniture market, in recent years there have been significant changes in the qualitative nature: closing of national markets, internationalization of furniture production. These factors largely determine the changes in the dynamics and structure of the international furniture retail. Russia's accession to the WTO will undoubtedly lead to low-price competition in the segment due to the increased supply of furniture of economy class. However, Russian producers have time to prepare for this situation, and to diversify its furniture retail, since the reduction of customs duties on furniture and materials for it must happen only by 2018.

Keywords: diversification, furniture retail, export, market segment, competitiveness, international business.

\section{Introduction}

\subsection{Furniture retail in Russia: status, problems and prospects}

Over the past few years, the increase in demand for furniture was stimulated by such factors as rising incomes, increasing housing construction, introduction of schemes for mortgage and consumer lending. Russian furniture market has been developing dynamically. In the first place, it is connected with the development of the real estate market: with the increase in the input of residential areas, with the resettlement program of old and dilapidated housing, etc. Consumers are changing the old furniture to the new, as well as they are engaged in redevelopment of apartments, construction of country cottages. The latter requires a change in approach to the production of furniture, as companies producing kitchen, cabinet, upholstered furniture, and office. The furniture market is constantly changing and improving. 
Every year there are new trends in terms of consumer preferences, fashion, materials of production. In the past two years, furniture of high quality made of particleboard and natural file remains popular. In the color scheme white and light colors - milk, beige, etc. remains fashionable. One of the major trends is the combination of bright colors with colorful and vivid colors. As the basic material and decorative material leather is popular, this is used not only as upholstery of sofas and chairs, but also for decoration of beds and tables. As for the design of various domestic premises, the furniture for bedrooms and living room is mostly done in classic style, but as kitchen furniture products in high-tech style is trendy. Competition in the Russian furniture market remains low, in the market there are a few major players, the rest ones belong to small and medium businesses. In this connection, the Russian furniture retail is at an early stage of its development. The market is highly fragmented: the number of big players is very small, and their combined share does not exceed $10-12 \%$.For today on Russian furniture market there are three basic types of sales channels: multi-brand network, mono-brand corporate networks of producers and small independent dealers. Most of the networks operating in multi-brand furniture supermarket format are created in the regions. For today one of the main problems in the development of an independent multi-brand networks is the formation of the optimal range and pool of suppliers.

\subsection{Fundamentals of diversification of furniture retail}

The problem of diversification of furniture retail in Russia is highly relevant in connection with the necessity to release this business in the international arena and it is associated with the expansion of the activity of large firms, companies that go beyond the core business, which refers to the production. Diversification is the major component of the structure of modern market economy, which has a significant impact on the division of labor, competition and efficiency. Borders of diversification are very mobile. The more activities in the furniture enterprise we have, the higher the level of diversification we got. In this case, diversification means adjustment of the main (production) activity, and substantial reorientation of strategy. Diversification is stimulated by the desire of enterprises in a competitive environment to strengthen its position in the market in a timely manner to respond to the changing economic environment and ensure its effectiveness. As a result of diversification, enterprise restructures their production for the modern technological and organizational level. Particular attention is paid to the attraction and use of highly qualified personnel. Having very higher level of $R \& D$, correctly chosen development strategy, been well aware of the situation on the market, furniture companies can identify new areas of expansion in the manufacturing and retail, as well as provisions for their implementation. Along with this diversification may be due to the reaction of businesses to the circumstances that threaten their well-being, such as falling demand for manufactured goods and services. Decision to diversify is also dictated by the desire of management to optimize the structure and size of the production. Risks associated with the production of new goods and services, as well as limited managerial, financial, commercial and other resources often push furniture companies in mergers and acquisitions. Most of the mergers have the character of concern or holding. In such structures, responsibility for decisions, and hence for ensuring profitability is delegated to the field. Higher management is exempt from the current planning and operational functions, focusing on the distribution of funds between the individual units, the implementation of the general strategy. Diversification through mergers is considered effective measure because it involves the acquisition of material resources and distribution channels, as well as management and qualified staff. And all this takes place without first competition for market share. But we must take into account the fact that diversified companies are able to overcome many barriers to entry into the market and thereby reduce the concentration in individual markets and stimulate competition.

\section{Method}

\subsection{Monitoring of prices and assortment of wholesale and retail companies}

Pricing analytics allows defining difference in the price of domestic furniture manufacturers and their foreign competitors. Analytics on assortment of furniture reveals the most recent changes in the range of interest within the target niche and opens up new competitive brands. Selective monitoring of the market shows complete picture of network competitors of furniture retail and thereby help to bring to realization of its own goods of most profitable customers. In addition to this function is the minimum analogue enables you to search product, similar to the characteristics for the given one but with the lowest price in the network. As a consequence, the result of determining the minimum analogue may be a decision to change the price or supplier of furniture products. Continuous monitoring it is monitoring of the entire product group. When it is carried out we determine the range and prices of competitors, considering features of interaction of network with suppliers. The result of continuous monitoring program can become an extension of their own range of products, or 
change of suppliers for more productive implementation in the future.

\subsection{Method of expert evaluations}

The method allows to identify the main trends in the furniture market and its regional characteristics. In each region, a dense survey $w$ of wholesale level and dense examination (except for Moscow and St. Petersburg) of retail link was conucted. In Voronezh, monitoring was carried out in 10 major retail outlets. The Russian market was presented in the study with the following regions: Central Federal District - Moscow, Voronezh, Lipetsk. Northwestern Federal District - St. Petersburg, Kaliningrad. Volga FD - Samara, Nizhny Novgorod, Kazan, Ulyanovsk, Naberezhnye Chelny, Togliatti. Urals - Yekaterinburg, Tyumen. Siberian Federal District - Omsk, Novosibirsk, Kemerovo. Far East Federal District Vladivostok. Southern Federal District - Rostov-on-Don. Monitoring of assortment of furniture was conducted on various types of furniture: sofas, furniture, kitchen, tables and chairs, suites (bedrooms, dining rooms, and living rooms). During monitoring, models of furniture, manufacturing country, type of finish and the material used in manufacturing were fixed, as well as the price of the furniture. Since the Russian furniture market is not branded, the distribution of representation of models of furniture in each region can not be done.

\subsection{Desk study}

Desk study - is a set of methods for the collection and evaluation of marketing information contained in the sources (statistics or reports), prepared to identify the prospects for development of furniture retailers. As part of the desk study following sources were used: data of trade press, data of industry concerns and holdings, materials of printed and electronic media, materials of international furniture exhibitions and conferences. Desk data collection methods are based on secondary sources, so it is often referred to as methods for working with documents. Material of both secondary (external and internal) sources and primary documents were used as the documents: the answers to open-ended questions of questionnaires, materials of focus groups and open-ended interviews. In carrying out desk research traditional methods of analysis of documents were used, namely informative and targeted analysis and content analysis of documents.

\subsubsection{Content analysis}

Formalized method of collecting data from secondary sources and qualitative and quantitative analysis of their content. Conducting content analysis is based on the following principles: the principle of formalization, where it is necessary to set unambiguous rules to identify the content of the desired characteristics; principle of statistical significance, i.e. interested content elements must occur with sufficient frequency. Algorithm of content analysis consists of the following steps: setting goals of content analysis; definition of categories of analysis; definition of the unit of analysis; range of quantitative and qualitative characteristics of text that which are of particular interest for researcher to characterize the relationship with content of external parameters; source selection for the survey; design tables of data collection for each category of analysis; collection of information; processing of the results and their interpretation; preparation of the report.

\subsubsection{Informative and targeted analysis}

It is intended to identify content and semantic structure of the text and to relate it with the concept of communication that allows you to detect possible deviations in the interpretation of the text from the other participants of communication, i.e. to assess the success of communication. Analyzing a given text as the embodiment of the author, the researcher tries to answer the following questions: why and what for something is said in the text? The concept of "information content" is the key for understanding informative and targeted analysis of documents. Informative and targeted analysis allows you to: assess the embodiment of communication objectives laid down in the text; determine the structure of the text; investigate the possibility of interpretation of the content of the text; ascertain the adequacy of the perception of the text; implement the "compression" of the text for easy analysis or work.

\section{Results}

Furniture retail in Russian Federation is continuing to be one of the most unstructured and non-clear markets of durable goods. To date, the Russian retail furniture manufacturers continue to dominate, but in the near future the situation may 
change: manufacturers will either allocate retail business into independent companies, or get rid of their own networks, often because its own retail of furniture manufacturers is much less effective than dealer shops. For now branded network of manufactures are the largest in number of outlets (own and partner). The share of multi-network companies in the Russian furniture market is $33 \%$ of the total sales volume. One of the leading trends in the development of the furniture market is increase of formats and increased percentage of large-format retail sales of furniture.

\subsection{Positive outlook for Russia}

In 2013, Russia is seen significant growth in market of furniture and furniture production by $8 \%$. This is facilitated by two major circumstances - an increase in new buildings placed in service, and, of course, increasing the income of citizens of the country. Special influence was made by individual orders, i.e. orders for the production of furniture by author original designs. Since 2010, active restoration furniture market began after the financial crisis. In 2013, Russia took the $15^{\text {th }}$ place in the ranking of the world's manufacturers of furniture, and on the capacity of the market it already occupies the $11^{\text {th }}$ place (climbed 5 places up from 2009). In the ranking of the world's importers of furniture Russia is on the ninth place (in 2002, it was on the 15th), whereas the volume of exports - only on the 46th. Over the last 2 years there is a growing competition between Russian and foreign manufacturers in virtually all segments of furniture products. However, during this period the expansion of Russian producers on foreign markets does not become more intense. The share of exports in the total volume of Russian furniture production in 2013 was about 12\% (according to preliminary data of the Customs Service of the Russian Federation).

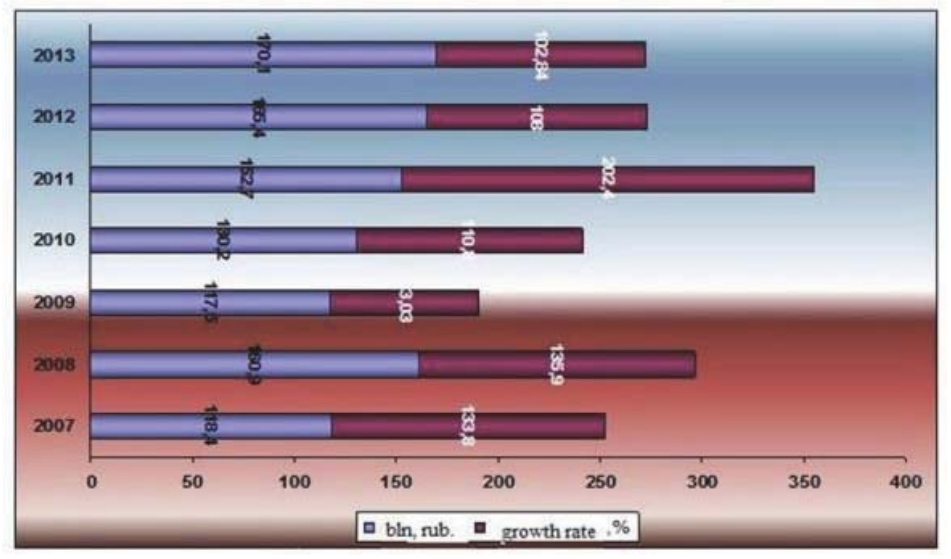

Figure 1. Volume of Russian furniture market

\subsection{The structure of the furniture retail}

At the moment, there are three main types of retailers, operating in Russia. The main criterion for determining the type of network was the breadth of the geographic scope of network outlets and turnover of network. International furniture retail is IKEA, Hoff, Leroy Merlin, OVI, Castorama. Federal furniture retail - main representatives is given it (Table 1).

Table 1. Major representatives of the federal furniture retail of Russia for 2013.

\begin{tabular}{|l|l|c|c|c|c|c|}
\hline The name of the trade network & Headquarters & Year of creation & $\begin{array}{c}\text { The number of } \\
\text { outlets, 2013 }\end{array}$ & $\begin{array}{c}\text { The number of } \\
\text { outlets, April 2014 }\end{array}$ & $\begin{array}{c}\text { Regions of } \\
\text { presence }\end{array}$ & Price category \\
\hline «Shatura Furniture» & Moscow & 1961 & 2057 & More than 2100 & All FD & $\begin{array}{c}\text { Average I } \\
\text { Above average }\end{array}$ \\
\hline «Stolplit» & Moscow & 1999 & 1929 & More than 2000 & $\begin{array}{c}\text { All, except } \\
\text { FEFD }\end{array}$ & Average \\
\hline «Dyatkov0» & $\begin{array}{l}\text { Dyatkovo, } \\
\text { Bryansk region }\end{array}$ & 2004 & 934 & More than 1000 & All FD & $\begin{array}{c}\text { Average I } \\
\text { Above average }\end{array}$ \\
\hline «Furniture of Chernozemye» & Voronezh & 1997 & 979 & More than 1000 & $\begin{array}{c}\text { All, except } \\
\text { FEFD }\end{array}$ & $\begin{array}{c}\text { Above average } \\
\text { /Luxury }\end{array}$ \\
\hline «Furniture factory March, 8» & Moscow & 1998 & 1959 & More than 2000 & $\begin{array}{c}\text { All, except } \\
\text { FEFD }\end{array}$ & Above average \\
\hline
\end{tabular}

Regional furniture retail - "Sofas and Armchairs", "Empire of Furniture", "Furniture Grad», «INVAGO». 


\subsection{Risks of the Russian furniture retail}

However, there are certain risks. Existing risks for furniture retail over the past year, it is primarily decrease in traffic to offline-stores and formation of pent-up demand. Overcome these risks and reach new growth opportunities are possible for furniture retailers using advanced Internet technology. This is facilitated by the growth of turns of online-trading. Russian consumers are actively developing not only online shopping, but also a mobile shopping. The way out of the situation of stagnation can be multi-channel strategy, suggesting synergy of offline and online-sales of furniture - joint and not separate development of these channels. Attention to the buyer will allow retailers to become more profitable.

\subsubsection{Key elements of effective retail}

Results of the analysis of the Russian furniture retail led to identifying 10 key elements of effective retailing. Customer Service - promotional offers remains a critical factor, but this factor alone is not enough. Emotional response is a relationship based on emotions, helping the brand to achieve success. For example, brands such as IKEA showed better results than most other supermarkets partly due to those relationships that they have managed to establish with customers. Features of behavior - it is necessary to focus on the smallest detail knowledge of consumer behavior. Profit maximization - it is necessary to increase the share of purchases of customers who pays the best interest. This will be a key factor in the partner relationship between suppliers and retailers. Loyal customers - it is need to form and encourage loyalty, which is particularly important in emerging markets. Underlining continuity - customers prefer to deal with wellknown brands. Demonstration of the profitability of their offers - even if the customer buys a less expensive item, it should feel as if bought something valuable. The interaction point - it is necessary use all points of interaction with clients as disappointment of customer can have serious consequences. Ensuring continuous growth is to track consumer trends, to spot unmet needs. Working with the media - it is necessary to use a variety of sources, including print media, television, radio, websites, brochures, catalogs, e-mail, text, Twitter, Apps, blogs, chats and YouTube.

\section{Discussion}

Competition with imports of furniture will become more visible and tight when in 2018 WTO rules will come into force, in consequence of which the taxation of Russian and imported furniture will be unified, that is the same tax rate is introduced. It should be noted that many Russian manufacturers, aware of the increased competition, are ready to take appropriate measures to profitably adapt to changes. For successful work in the furniture market is necessary: to expand the production area, has a large reserve of working capital to build inventory, keep a reference to the consumer, have developed sales network, and have certain market share and their own brand. In the structure of the furniture production in Russia the major segment is upholstered furniture, which contributes to the growth of the simplicity of the production technology. This is followed by segment of kitchen furniture. The most difficult segment in terms of production is furniture for living rooms and bedrooms. To produce them, expensive highly technical equipment is required. But it is the Russian furniture which is most exported to Germany, the Netherlands, Japan, Italy and the Scandinavian countries, where it is prized for its being environmentally friendly and competitive prices. The main contradiction is that the country which has the largest reserves of timber in the world is still not among the leading countries of furniture manufacturers. Our research has shown that the Russian furniture market is large, growing and fairly open, with promising prospects. Over the past decade, the Russian furniture industry took a giant step forward by investing in technical upgrading. That, however, did not help Russian furniture manufacturers to achieve greater competitiveness in the international market: furniture companies from Russia are still focused on domestic demand (and it is manages to be saturated only partially), while the share of export sales is small. Furniture enterprises of the Russian Federation have the power not only to conquer the markets of neighboring countries, but also to enter the higher levels of the Euro-Union. In our country, almost all the furniture industry has been privatized. Furniture companies have already faced the problems caused by the reverse side of independence from the state. Usually these problems have industry-wide character.

\section{Conclusion}

Russian furniture industry needs government support program to promote the development of the industry by investing in the process of modernization, improvement of financial discipline, which will continue to diversify furniture retail and strengthen export potential. Undoubtedly, investment projects require huge budgets, attracting credit resources of banks, and without a rational state support can not do. As a consequence, as a result of growth in production and exports return 
investment in the sector will take place, as well as import substitution and improvement of the quality of goods. In front of Russian furniture retailing there is an important problem not only to sell products, but to implement it with high efficiency, without intermediaries, ensuring maximum receipt of proceeds from sales in Russia. For this it is necessary to consider issues of marketing of finished products, to expand the geography of its supplies and finding new partners to consider questions of internal and external markets, to improve the work of the federal and regional furniture retail, and introduce new forms of trade.

\section{References}

Armand Dayan, Annie Troadec, Loicn Troadec. (2003). Promotion des Ventes et P.L.V. Saint Petersburg.

Armand Dayan, Les etudes de marche. (2003).

Bezrukova T.L., Morkovkina S.S., Russia B.B., Shanin I.I., Popkova E.G. (2013). Methodological approach to the identification of predictive models of socio-economic processes for investment and innovative development of enterprises / World Applied Sciences Journal. 2013. Vol. 27. No. 11. Pp. 1443-1449.

Bezrukova T.L., Borisov A.N., Shanin I.I. (2014). Solutions of the problem of innovative development of the furniture enterprises I Lesotekhnicheskii Zhurnal. 2014. No. 1(12). Pp. 229-235. DOI: 10.12737/3374. (rus).

Busarina Y.V. (2011). Advertising as a marketing tool of relationships with customers in the furniture market (article) PES: Finance. Economy. Strategy. Ser. Innovative economy: the human dimension. No. 11. - Pp. 69-72.

David D'Alessandro. (2008). Career Warfare: 10 Rules for Building a Successful Personal Brand on the Business Battlefield.

Portal about commercial real estate and retail. (2015). DOI: http://www.shopandmall.ru/mags.php?category=21

Proper personnel policies will help retail to grow faster. (2014). DOI: http://www.retailmagazine.ru/article.php?numn=7054

Retail and online retail in Russia operating statistics for the III quarter of 2013. DOI: http://content.enter.ru/wp-content/uploads/ 2013/12/Russian-retail-online-retail-3rd-quarter-2013_RUS.pdf

Risks and opportunities of the Russian retail. (2015). DOI: http://www.dv-reclama.ru/russia/articles/20921/riski_i_vozmozhnosti_ rossiyskogo_riteyla_10_klyuchevykh_elementov_effektivnoy_roznichnoy_torgovli/

Stepanova Y.N., Busarina Y.V. (2014). Innovative development of furniture retail in the Russian Federation (article) Innovative Kazakhstan's economy: sustainable development in a globalizing world: Coll. materials of the international scientific conference of young scientists. - Astana: Eurasian National University named after LN Gumilev. I Part. - Pp. 313-317.

Stewart, G. Bennett. (1991). Quest for Value: A Guide for Senior Managers - STC-Hi Marketing.

Trading restart: federal retailers prepared for the crisis in 2014. DOI: http://navigator-kirov.ru/newspaper_articles/31451.html

World and Russian retail 2009-2016. Draw conclusions and make plans. (2015). DOI: http://content.enter.ru/wp-content/uploads/ 2013/06/Worldwide-Russian-Retail-2009-2016_RUS_Publication.pdf 